\title{
Sulfation of Chondroitin Sulfate and Related Sugar Chains
}

\section{コンドロイチン硫酸および関連糖鎖の硫酸化}

\author{
Habuchi, Osami \\ Department of Life Science, Aichi University of Education, Igaya-cho, Kariya, Aichi 448-8542, Japan \\ FAX : 81-566-26-2649, E-mail : ohabuchi@ auecc.aichi-edu.ac.jp
}

Key Words : chondroitin sulfate, PAPS synthesis, sulfate transport, sulfotransferase

\begin{abstract}
Sulfotransferases so far cloned which are involved in the synthesis of chondroitin sulfate are classified into three gene families: chondroitin 6-sulfotransferase (C6ST) family, chondroitin 4-sulfotransferase (C4ST) family and uronosyl 2-Osulfotransferase (UA2OST) family. The C6ST family includes sulfotransferases which catalyze the transfer of sulfate to position 6 of Gal residue of keratan sulfate and sialyllactosamine oligosaccharide, and to position 6 of nonreducing terminal GlcNAc residue. In the C4ST family, sulfotransferases which catalyze the transfer of sulfate to position 4 of nonreducing terminal GalNAc residue and to position 3 of nonreducing terminal GlcA residue are present. UA2OST was cloned as a cDNA showing homology with heparan sulfate 2-sulfotransferase that transfers sulfate to position 2 of Ido A residue in heparan sulfate. It became evident that, in some cases, sulfotransferases involved in the sulfation of glycosaminoglycans and sulfotransferases involved in the sulfation of oligosaccharides of glycoproteins are included in a common gene family. A sulfotransferase with a novel specificity may be found in these families, or a new sulfotransferase other than known families may be revealed in the future. Findings of a new sulfotransferase will offer important information about the biological function of sulfated sugar chains.
\end{abstract}

\section{A. Introduction}

There is significant structural diversity in chondroitin sulfate isomers (including dermatan sulfate that is related to chondroitin sulfate in its biosynthesis and structure). The position and number of sulfate residue attached to the repeating disaccharide units as well as the kind of component sugars contribute to the formation of the divergent structures. The structural diversity is thought to reflect the divergent biological functions. Recently, marked advances in the cloning and characterization of the sulfotransferases involved in the synthesis of chondroitin sulfate and related sugar chains have been achieved. An intimate relationship between the sulfation of chondroitin sulfate and the sulfation of glycoprotein oligosaccharides became apparent from studies on the molecular nature of each
要 約

今までにクローニングされたコンドロイチン硫酸の合成に 関わる硫酸転移酵素は、コンドロイチン6 硫酸転移酵素(C6ST)、 コンドロイチン 4 硫酸転移酵素(C4ST)、ウロノシル 2-O-硫酸転 移酵素(UA2OST)の3つの遺伝子ファミリーに分類される。C6ST のファミリーには、ケラタン硫酸やシアリルラクトサミンのGal 残基の 6 位、非還元末端のGlcNAc残基の 6位を硫酸化する硫酸 転移酵素が含まれる。C4STファミリーには、非還元末端の GalNAc残基の 4 位、非還元末端GlcAの 3 位を硫酸化する硫酸 転移酵素が含まれる。UA2OSTは、ヘパラン硫酸のIdoAの 2 位 を硫酸化する硫酸転移酵素との相同性により得られた。硫酸転 移酵素のクローニングにより、グリコサミノグリカンと糖タン パク質糖鎖の硫酸化は、同じ遺伝子ファミリーに属する硫酸転 移酵素により行われることが明らかになった。これらの遺伝子 ファミリーからさらに新たな硫酸転移酵素が見いだされるかも しれない。またこれら以外の新たな遺伝子ファミリーに属する 硫酸転移酵素が今後発見されるかもしれない。新たな硫酸転移 酵素の発見は、硫酸化糖鎖の生物学的機能を明らかにするのに 重要な情報を提供するであろう。

A. はじめに

コンドロイチン硫酸(生合成的、構造的に関連を持つデルマ タン硫酸を含める)は、二糖繰り返し構造に含まれる構成糖の種 類、硫酸基の結合位置の組み合わせにより、構造多様性を示 す。コンドロイチン硫酸の多様構造は生物学的な機能の多様性 と深い関連があると考えられる。コンドロイチン硫酸の多様構 造の形成に関わる硫酸転移䤉素遺伝子のクローニングはこの数 年の間に大きく進展した。さらに、硫酸転移酵素遺伝子のク ローニングを通して、コンドロイチン硫酸の硫酸化と糖タンパ ク質糖鎖の硫酸化の密接な関係が明らかになってきた。本稿で 


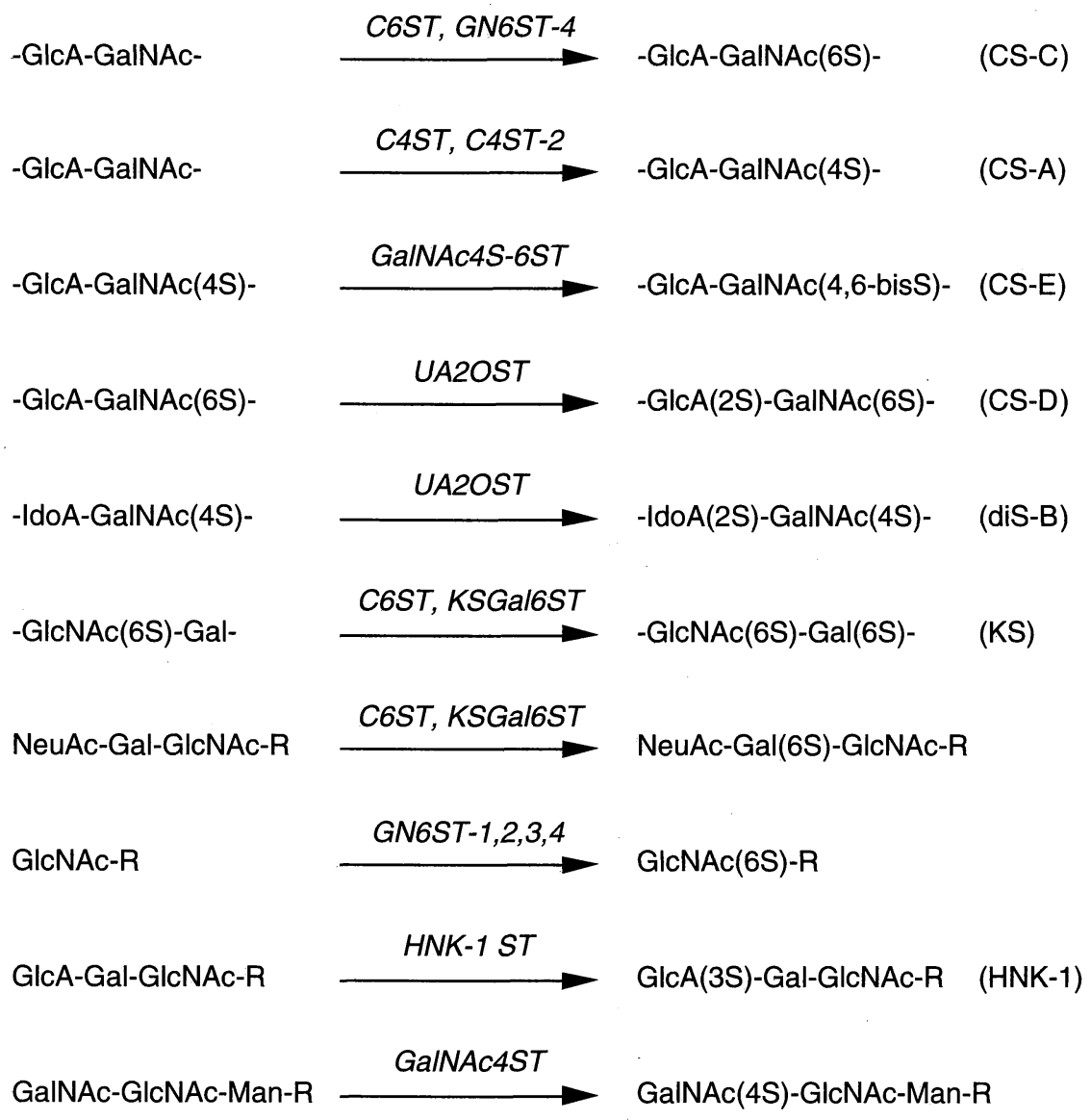

Fig. 1. Substrate specificity of sulfotransferases involved in the sulfation of chondroitin sulfate and related sugar chains. For the abbreviation of each sulfotransferase, see the text.

sulfotransferase. In this review, I have summarized the properties of the sulfotransferases involved in the synthesis of chondroitin sulfate and the related sugar chains. I also describe the uptake of sulfate ion and synthesis of 3'-phosphoadenosine 5'phosphosulfate (PAPS) that occur before the transfer of sulfate by the sulfotransferases. Sulfotransferases involved in the synthesis of heparan sulfate have been reviewed previously $(1,2)$. Figure 1 shows the acceptor substrate specificity of each sulfotransferase.

\section{B. Transport of Sulfate Ion}

Every sulfotransferase transfers sulfate from PAPS to the defined position of the sugar residues. Sulfate ion, which is one of the source materials for the production of PAPS, is transported from the extracellular milieu or supplied from sulfur-containing amino acids. Diastrophic dysplasia (DTD) is autosomal recessive osteochondrodysplasia with clinical features including dwarfism, spinal deformation and specific joint abnormalities. DTD gene was identified as a gene encoding sulfate/chlo-
はコンドロイチン硫酸と関連糖鎖の硫酸化に関わる硫酸転移酵 素、および硫酸基転移反応の前段階である硫酸イオンの輸送と PAPS合成についてまとめた。へパラン硫酸合成に関する硫酸転 移酵素については他の文献 $(1 、 2)$ を参照されたい。コンドロイチ ン硫酸および関連糖鎖の硫酸化に関わる硫酸転移酵素の特異性 を図1に示した。

\section{B. 硫酸イオンの膜透過}

糖鎖の特定の位置に結合した硫酸基は、特異的な硫酸転移 酵素の働きでPAPSから転移される。PAPS の原料の一つ硫酸イ オンは、硫酸イオントランスポーターにより細胞外から輸送さ れるか、細胞内の含硫アミノ酸の代謝により供給される。矮小 発育、脊椎変形、関節異常を示す常染色体劣性の遺伝疾患 $\mathrm{di}$ - 
ride antiporter (DTDST) (3). Mutations in DTDST gene were also found in the lethal chondrodysplasia, achondrogenesis type 1B (4) and McAlister dysplasia (5). Fibroblasts with the most severe clinical phenotype showed the lowest sulfate uptake (5). Undersulfation of proteoglycan synthesized by chondrocytes from achondrogenesis type 1B (6) and McAlister dysplasia (5) was evident. A unique characteristic of high endothelial venules (HEV) endothelium is the capacity of HEV endothelial cells (HEVEC) to incorporate large amounts of inorganic sulfate. Large amounts of sulfate ion may be required for the synthesis of L-selectin ligand, sulfated sialyl Lewis X. Uptake of sulfate by HEVEC was inhibited by 4,4'-diisothiocyanostilbene-2,2'disulfonic acid (DIDS), an inhibitor of sulfate/chloride antiport, but about $50 \%$ of the uptake was resistant to DIDS, indicating the presence of another sulfate transport in these cells. From HEVEC cDNA library, SUT-1 gene, which is a homologue of a rat $\mathrm{Na}^{+}$-dependent sulfate transporter, was cloned (7). When SUT-1 cDNA was injected to Xenopus laevis oocytes, $>30$-fold stimulation of $\mathrm{Na}^{+}$-dependent sulfate uptake was observed. DTDST gene was expressed in all tissues examined (3), whereas, SUT-1 gene was expressed in the placenta and HEV (7), suggesting the specific function of SUT-1.

\section{Synthesis of PAPS and the Nuclear Localization of PAPS Synthetase}

PAPS, one of the substrates for sulfotransferases, is a universal donor of the sulfate group in every organism. Sulfation of chondroitin sulfate is largely regulated by the level of PAPS synthesis. Murine brachymorphism is characterized by a domeshaped skull, short thick tail, and shortened limbs. The phenotype is inherited as an autosomal recessive. Since chondrocytes of brachymorphic mouse synthesized undersulfated proteoglycan, and showed decreased PAPS synthetase activity, this mutant was assumed to have defective PAPS synthetase (810). PAPS is synthesized through two successive enzyme reactions as follow:

$$
\begin{array}{lll}
1: \mathrm{SO}_{4}^{2-}+\mathrm{ATP} & \rightarrow & \mathrm{APS}+\mathrm{PPi} \\
2: \mathrm{APS}+\mathrm{ATP} & \rightarrow & \mathrm{PAPS}+\mathrm{ADP}
\end{array}
$$

Reaction 1 is catalyzed by ATP-sulfurylase and reaction 2 by APS-kinase. These enzymes are different proteins in bacteria, fungi and yeast. On the other hand, in higher organisms, these two enzymes were assumed to be contained in a bifunctional protein, because the purified PAPS synthetase from chondrosarcoma showed two activities (11). This assumption was confirmed by cloning PAPS synthetase (12). Mouse PAPS synthetase 1 deduced from the cDNA contains APS-kinase domain with 199 amino acids and ATP-sulfurylase domain with 389 amino acid. A 37-amino acid stretch is present between the two domains. Human PAPS synthetase 1 was cloned from HEV cDNA library (13). The introduction of human PAPS synthetase $1 \mathrm{cDNA}$ into CHO cells resulted in a high level of PAPS pro- astrophic dysplasia(捻曲性骨異形成症)の原因遺伝子が、 $\mathrm{SO}_{4}{ }^{2} / \mathrm{Cl}$ ア ンチポートを行うトランスポーター(DTDST)と同定された(3)。 致死性の遺伝疾患である achondrogenesis type 1B (4)やMcAlister dysplasia (5)もこの遺伝子に変異を持つことが明らかにされた。 症状の重さはDTDST の残存活性によることが皮虐線維芽細胞の 硫酸イオンの取り込みにより示された(5)。achondrogenesis type 1B (6)、McAlister dysplasia (5) では軟骨で合成されるコンドロイ チン硫酸の低硫酸化が起きていた。高内皮細静脈の内皮細胞 (HEVEC)は硫酸イオンを取り込む活性が高いことが知られてい た。これは L-セレクチンリガンドである硫酸化糖鎖を合成する ために必要と考えられる。HEVECによる硫酸イオンの取り込み は、 $\mathrm{SO}_{4}^{2}$ \% Clアンチポートの阻害剂である4, 4'-diisothiocyanostilbene-2, 2'-disulfonic acid (DIDS)により阻害されるが、約 50\%の活 性が DIDS抵抗性を示すので、HEVECにはDTDST以外に別の硫 酸イオントランスポーターが存在することが考えられ、ラット の $\mathrm{Na}^{+}$依存性 $\mathrm{SO}_{4}^{2-}$ トランスポーター遺伝子と相同性を示す遺伝 子(SUT-1遺伝子)がヒト HEVECのライブラリーからクローニン グされた (7)。この遺伝子産物がトランスポーター活性を持つこ とは、cDNAをアフリカツメガエル卵母細胞に注入すると $\mathrm{Na}^{+}$依 存性の硫酸イオンの取り込みが30倍以上に増加することにより 示された。DTDST遺伝子が多くの組織で発現しているのに対 し、SUT-1遺伝子は胎盤と HEVで選択的に発現しており、特異 的な機能を担っていることが考えられる。

\section{PAPSの合成およびPAPS合成酵素の核への局在}

PAPS は硫酸転移酵素の基質であり、生物界での硫酸基の普 遍的な供与体である。コンドロイチン硫酸の硫酸化はPAPSの 合成によって大きく調節されている。Brachymorphic (bm) mouse (短型マウス)はドーム型の頭蓋、太くて短い尾、短肢を特徵と し、その形質は常染色体劣性の遺伝子により伝えられる。bm mouseでは軟骨の PAPS合成酵素活性が減少していることから、 PAPS合成酵素に変異があると推定された (8-10)。PAPS は硫酸 イオンとATPから次の2段階の反応で合成される。

$$
\begin{array}{lll}
1: \mathrm{SO}_{4}{ }^{2-}+\mathrm{ATP} & \rightarrow & \mathrm{APS}+\mathrm{PPi} \\
2: \mathrm{APS}+\mathrm{ATP} & \rightarrow & \mathrm{PAPS}+\mathrm{ADP}
\end{array}
$$

1の反応を行うのがATP-スルフリラーゼ、2 の反応を行うの がAPS-キナーゼである。細菌、カビ、酵母な゙ではこれらの酵 素は独立した別のタンパク質として存在している。一方軟骨肉 腫細胞から精製されたPAPS合成酵素は両方の酵素活性を持つこ とから、高等生物では 2 機能を持つ単一タンパク質として存在 すると考えられていたが (11)、PAPS 合成酵素の遺伝子のクロー ニングにより証明された (12)。マウスからクローニングされた PAPS合成酵素 1 は、199 残基のアミノ酸からなるAPS-キナーゼ ドメイン、389アミノ酸残基からなる ATP-スルフリラーゼドメ イン、およびそれらをつなぐ37アミノ酸残基の部分から構成さ れる。ヒトのPAPS合成酵素 1 が高内皮細静脈内皮細胞のライブ ラリーからクローニングされた (13)。ヒトPAPS 合成酵素1を導 
duction. Chlorate treatment of the transfected CHO cell inhibited PAPS synthetase activity. Mouse PAPS synthetase 1 gene was located to chromosome 3 , while bm gene was located to chromosome 19, indicating that PAPS synthetase 1 gene is not responsible for the phenotype of bm. PAPS synthetase 2, which is a homologue of PAPS synthetase 1, was cloned (14). PAPS synthetase 2 gene was demonstrated to be responsible for the expression of bm phenotype because (a) PAPS synthetase 2 gene was located at chromosome 19, (b) PAPS synthetase gene from bm mouse showed mutation in the kinase domain (Gly79 to Arg), (c) the APS-kinase activity of the mutated PAPS synthetase 1, which was expressed in E. coli and affinity purified, showed less than one-tenth activity of normal PAPS synthetase 1, although ATP-sulfurylase activity of the mutant protein was normal. Missense and nonsense mutations in the APS-kinase domain of PAPS synthetase 2 were demonstrated in the human inherited disorder, spondyloepimetaphyseal dysplasia (15).

While PAPS synthesis has been assumed to occur in the cytosol, human PAPS synthetase 1 was shown to accumulate in the nucleus of mammalian cells, suggesting that PAPS may be synthesized in the nucleus as well (16). When PAPS synthetase 1 cDNA was transfected in CHO cells or COS-7 cells, the expressed protein was located in the nucleus. The nuclear localization of PAPS synthetase 1 was shown in the endogenous enzyme of ECV endothelial cells. When transfected in yeast with methionine auxotrophy caused by a deficient ATP-sulfurylase or APS-kinase, PAPS synthetase 1 was localized in the nucleus and rescued the methionine auxotrophy of the strain, indicating that PAPS synthetase was fully functional when localized to the nucleus. Unlike PAPS synthetase 1, ectopically expressed PAPS synthetase 2 in COS-7 cells or $\mathrm{CHO}$ cells was found to accumulate in the cytoplasm. However, cotransfection of PAPS synthetase 1 and PAPS synthetase 2 shifted the latter from a cytosolic to a nuclear localization. The APS-kinase domain of PAPS synthetase 1 was shown to be necessary and sufficient for the nuclear localization.

Transporters of nucleotide sugars and nucleotide sulfate, which are involved in the transport of these materials into the Golgi apparatus or ER, have been found (17). PAPS transporter has been purified from rat liver Golgi fraction $(18,19)$, but cloning of the transporter has not been reported.

\section{Purification, Substrate Specificity and Cloning of the} Sulfotransferases Involved in the Synthesis of Chondroitin Sulfate

Among the sulfotransferases involved in the synthesis of chondroitin sulfate, chondroitin 6-sulfotransfersase(C6ST), chondroitin 4-sulfotransferase (C4ST) and uronosyl 2-Osulfotransferase have been cloned. GalNAc 4-sulfate 6-Osulfotransferase (GalNAc4S-6ST) involved in the synthesis of chondroitin sulfate $\mathrm{E}$ has been purified from squid cartilage and
入した CHO細胞ではPAPS合成活性が増加したが、塩素酸イオ ンの添加によりPAPS合成は阻害された。PAPS合成酵素1遺伝子 はマウスでは第3染色体にあるが、bm 遺伝子は第19染色体にあ るので、PAPS合成酵素1の変異が bm の原因とは考えられない。 PAPS合成酵素1の相同遺伝子の、PAPS 合成酵素 2 がクローニン グされた (14)。この遺伝子は次の結果から bm の原因と考えら れた。(a) PAPS 合成酵素 2 遺伝子が第19染色体にあること、 (b) bm mouseの持つ PAPS合成酵素 2 遺伝子には APS-キナーゼ ドメインに含まれる79番目の Glyが Argに変異していること、(c) 変異した遺伝子を大腸菌に導入し、発現したタンパク質をア フィニティー精製したところ、ATP-スルフリラーゼ活性は対照 と同じであるのに対し、APS-キナーゼ活性は対照の10分の1以下 となった。ヒトの遺伝疾患 spondyloepimetaphyseal dysplasia(脊 椎・骨端・骨幹端ジストロフィー)では PAPS 合成酵素 2 の APSキナーゼドメインにナンセンス変異、ミスセンス変異が検出さ れた (15)。

PAPS 合成はサイトゾルで起きると考えられてきたが、 PAPS合成酵素 1 が核に局在することから、核でのPAPS合成の 可能性が示された (16)。CHO 細胞やCOS-7細胞にPAPS合成酵 素1の遺伝子を導入すると、発現したタンパク質は核に局在し た。核への局在はヒトのECV内皮細胞が持っている内在性の PAPS合成酵素 1 でも示された。APSスルフリラーゼまたはAPSキナーゼの変異によりPAPS合成活性が欠損し、Met要求性と なった酵母に、PAPS合成酵素 1 遺伝子を導入すると、発現した PAPS合成酵素1は核に局在し、酵母はMet要求性を示さなくなっ た。このことは核に局在したPAPS合成酵素1が機能を持つこと を示している。PAPS合成酵素2の遺伝子を COS-7細胞やCHO 細 胞に導入すると、発現したタンパク質は核ではなくて細胞質に 分布する。しかしPAPS 合成酵素1の遺伝子を同時に導入する と、PAPS 合成酵素 2 核に局在するようになる。核に局在する シグナルは、PAPS合成酵素 1の APS-キナーゼドメインにあるこ とが示された。

ゴルジ膜やER膜にはサイトゾルから糖ヌクレオチドや PAPSを輸送する選択的なトランスポーターが存在している (17)。PAPSのトランスポーター活性を持つタンパク質が精製さ れているが (18、19)、遺伝子クローニングはまだ報告されてい ない。

D. コンドロイチン硫酸合成に関与する硫酸転移酵素の精製、特 異性、クローニング

コンドロイチン硫酸合成に関与すると考えられる硫酸転移 酵素のうち、今までにコンドロイチン 6 硫酸転移酵素 (C6ST)、 コンドロイチン 4 硫酸転移酵素(C4ST)、ウロノシル 2-O-硫酸転 移酵素(UA2OST)がクローニングされた、コンドロイチン硫酸 $\mathrm{E}$ の合成に働くGalNAc4 硫酸 6硫酸転移酵素(GalNAc4S-6ST)がイ 
characterized.

\section{D-1. Chondroitin 6-Sulfotransferase (C6ST)}

A sulfotransferase of $75 \mathrm{kDa}$, which transfers sulfate to position 6 of GalNAc residue, was purified to homogeneity from the serum-free culture medium of chick embryo chondrocytes (20). Since the same size of C6ST was obtained from chicken serum, secretion of C6ST into the extracellular space seems to occur not only in the culture condition but also in the physiological state (21). Based on the amino acid sequence, cDNA of C6ST was cloned from chick embryo chondrocyte library (22). The deduced protein had a type II transmembrane topology. C6ST catalyzed transfer of sulfate to position 6 of GalNAc residues of chondroitin, position 6 of Gal residue of keratan sulfate (23) and sialyl lactosamine oligosaccharides (24). C6ST-2 that catalyzed sulfation of position 6 of GalNAc residue of chondroitin was cloned (25). The same enzyme was cloned independently by other groups as an enzyme that catalyses sulfation of position 6 of nonreducing terminal GlcNAc residue (see below).

\section{D-2. Chondroitin 4-Sulfotransferase (C4ST)}

C4ST, which catalyzes transfer of sulfate to position 4 of GalNAc residue of chondroitin, was purified from the serum free culture medium of rat chondrosarcoma cells (26). The purified C4ST catalyzed transfer of sulfate to not only chondroitin but also desulfated dermatan sulfate. When the sulfated products formed from desulfated dermatan sulfate was digested with chondroitinase ACII, about half of the products were converted to $\triangle \mathrm{Di}-4 \mathrm{~S}$ and small amounts were recovered in monosulfated tetrasaccharide and monosulfated hexasaccharide fractions. On the other hand, the desulfated dermatan sulfate was hardly depolymerized by digestion with chondroitinase ACII. These results suggest that C4ST preferentially transferred sulfate to GlcArich domain contained in the desulfated dermatan sulfate. When the tetrasaccharide obtained from the ${ }^{35} \mathrm{~S}$-labeled desulfated dermatan sulfate after digestion with chondroitinase ACII was treated with mercuric acetate, ${ }^{35} \mathrm{~S}$-radioactivity was recovered exclusively in GalNAc4-sulfate (our unpublished data). C4ST thus appears to transfer sulfate to GalNAc residue adjacent to reducing side of GlcA, but not to GalNAc residue adjacent to reducing side of IdoA. These results indicate that C4ST recognizes not only position of GalNAc residue but also structure of the neighbouring sugar residue.

On the basis of the amino acid sequence of the purified C4ST, mouse C4ST cDNA was cloned (27). The deduced protein from the nucleotide sequence of the cDNA was a type II transmembrane protein with $\mathrm{N}$-linked oligosaccharides as observed in glycosaminoglycan sulfotransferases so far cloned. C4ST did not show any significant homology to other glycosaminoglycan sulfotransferases so far cloned, but $29 \%$ identity of amino acid sequence was found between C4ST and HNK-1 sulfotransferase. HNK-1 sulfotransferase transfers sulfate to position 3 of Glc A to yield GlcA $\left(3 \mathrm{SO}_{4}\right) \beta 1-3 \mathrm{Gal} \beta 1-4 \mathrm{GlcNAc} \beta 1-$
カの軟骨から均一に精製され、性質が調べられた。

\section{D-1.コンドロイチン 6 硫酸転移酵素(C6ST)}

コンドロイチン硫酸のGalNAc 残基の6位を硫酸化する75 $\mathrm{kDa}$ の酵素 $(\mathrm{C} 6 \mathrm{ST})$ がニワトリ培養軟骨細胞の無血清培養液から 均一に精製された (20)。同じ分子量の酵素がニワトリ血清から も得られているので(21)、硫酸転移酵素の細胞外への分泌が培養 という環境だけでなく、生理的条件でも起きていると考えられ る。精製 $\mathrm{C} 6 \mathrm{ST}$ のアミノ酸配列に基づきcDNA がクローニングさ れた(22)。cDNAから推定されるタンパク質はII 型膜タンパク質 であった。C6STはコンドロイチンの GalNAc残基の 6 位だけで なく、ケラタン硫酸のGal残基の 6 位(23)、シアリルラクトサミ ン構造を持つオリゴ糖のGal残基の 6 位を硫酸化した(24)。コン ドロイチンの GalNAc 残基に硫酸基を転移する C6ST-2がクロー ニングされた (25)。この酵素は GlcNAc-6-硫酸転移酵素活性を 持つ酵素として別のグループがクローニングした酵素と同一の タンパク質であった(後述)。

D-2. コンドロイチン 4 硫酸転移酵素(C4ST)

コンドロイチンの GalNAc残基の 4 位を硫酸化するC4STは、 ラットコンドロザルコーマ細胞の培養液から均一に精製された (26). 精製 C4STはコンドロイチン、脱硫酸化デルマタン硫酸に 硫酸基を転移した．硫酸基を転移された脱酸化デルマタン硫酸 をコンドロイチナーゼACII で消化すると、約 50\% の放射能が $\triangle \mathrm{Di}-4 \mathrm{~S}$ に回収され、 1 硫酸化 4 糖、 1 硫酸化 6 糖の位置にも少し 回収されたが、高分子部分には殆ど放射能は残らなかった。受 容体に用いた脱硫酸化デルマタン硫酸はコンドロイチナーゼ ACIIでほとんど低分子化しないことを考慮すると、C4STが脱硫 酸化デルマタン硫酸を受容体とするときは、GlcAを含む部分に 選択的に硫酸基を転移することが考えられる。コンドロイチ ナーゼACI消化で生じる 4 糖を単離し、酢酸水銀との反応で 3 糖 とし、コンドロイチナーゼABCで分解すると、 $\operatorname{GalNAc}\left(4 \mathrm{SO}_{4}\right)$ の みが生じたので(筆者ら未発表)、C4STはGlcAの還元側に隣接す るGalNAc残基に硫酸基を転移するが、IdoAの還元側に隣接する GalNAc残基には転移しないと考えられる。これらの結果は、 C4STはGalNAc残基の位置に関して特異的であるだけでなく、隣 接する糖鎖の構造も認識することを示している。

精製したC4STのアミノ酸配列に基づき、C4STのcDNAがク ローニングされた (27)。cDNAの塩基配列からアミノ酸配列を 推定すると、C4STは今までにクローニングされたグリコサミノ グリカン硫酸転移酵素と同じく、N-結合糖鎖を持つ II 型膜糖夕 ンパク質であった。C4STはその他のグリコサミノグリカン硫酸 転移酵素のいずれとも有意な相同性を示さなかったが、意外に も HNK-1 硫酸転移酵素とアミノ酸配列で 29\%一致した。HNK- 
R (HNK-1 epitope) $(28,29)$. Although acceptor substrate specificities are quite different from each other, C4ST and HNK-1 sulfotransferase seem to belong to a common sulfotransferase family. Mouse C4ST was expressed in brain and kidney (27). In contrast, human C4ST was expressed in peripheral leukocytes and colorectal adenocarcinoma cell $(30,31)$. Human C4ST (C4ST-1) and the second member of C4ST, C4ST-2 were cloned independently from the EST clones showing homology to HNK1 sulfotransferase (30). Sulfotransferase activity of the expressed C4ST-2 was much lower than that of C4ST. Human C4ST gene was mapped to 12q23.2-q23.3 (31).

\section{D-3. Uronosyl 2-O-Sulfotransferase (UA2OST)}

UA2OST was cloned from human lymphoma Raji cell as a cDNA showing homology to heparan sulfate 2sulfotransferase (33), which transfers sulfate to position 2 of IdoA of heparan sulfate and involved in the formation of bFGFbinding domain (32). When this cDNA was transfected in Sf9 insect cells, activity of sulfotransferase, which catalyzed transfer sulfate to dermatan sulfate and chondroitin sulfate, was overexpressed. Sulfation of dermatan sulfate occurred at position 2 of IdoA adjacent to $\operatorname{GalNAc}\left(4 \mathrm{SO}_{4}\right)$, whereas sulfation of chondroitin sulfate occurred at position 2 of IdoA adjacent to GalNAc $\left(6 \mathrm{SO}_{4}\right)$.

\section{D-4. GalNAc 4-Sulfate 6-O-Sulfotransferase (GalNAc4S- 6ST)}

GalNAc4S-6ST transfers sulfate to position 6 of GalNAc $\left(4 \mathrm{SO}_{4}\right)$ residues of chondroitin sulfate to yield disaccharide unit of chondroitin sulfate $\mathrm{E}$. This sulfotransferase was purified to homogeneity from squid cartilage containing large amounts of chondroitin sulfate E (34). The purified enzyme showed a broad band of $63 \mathrm{kDa}$ on SDS-PAGE. The protein bands of $63 \mathrm{kDa}$ disappeared after $N$-glycosidase $\mathrm{F}$ digestion, and protein bands of 38 and $40 \mathrm{kDa}$ appeared, indicating that the purified protein contained $N$-linked oligosaccharides as observed in C6ST and C4ST. The purified enzyme transferred sulfate to chondroitin sulfate $\mathrm{A}$, chondroitin sulfate $\mathrm{C}$ and dermatan sulfate. A low activity was observed toward squid skin chondroitin. The transfer of sulfate to chondroitin sulfate $A$ and dermatan sulfate occurred at position 6 of the internal GalNAc $\left(4 \mathrm{SO}_{4}\right)$ residues. Sulfation of chondroitin occurred at position 6 of $\mathrm{GaNAc}\left(4 \mathrm{SO}_{4}\right)$ residues but not at position 6 of GalNAc residues, which are contained in abundance in chondroitin. When a 4-sulfated trisaccharide and pentassaccharide, which bear $\mathrm{GalNAc}\left(4 \mathrm{SO}_{4}\right)$ residue at the nonreducing terminal, were used as acceptors, 27 and $40 \%$, respectively, of the total incorporation were found in the nonreducing terminal GalNAc(4,6-bis $\mathrm{SO}_{4}$ ), indicating that GalNAc4S-6ST is able to transfer sulfate not only to the internal GalNAc $\left(4 \mathrm{SO}_{4}\right)$ but also to the nonreducing terminal GalNAc $\left(4 \mathrm{SO}_{4}\right)$. The $K_{\mathrm{m}}$ for chondroitin sulfate A was about ten times as large as the $K_{\mathrm{m}}$ for
1硫酸転移䤉素はGlcA $\beta$ 1-3Gal $\beta$ 1-4GlcNAc $\beta$ 1-Rの非還元末端の GlcAの 3位を硫酸化する $(28 、 29)$ 。C4ST と HNK-1 硫酸転移酔素 は、糖残基と転移される位置に関しては全く特異性が異なるに もかかわらず、配列に相同性を示すことから、共通の硫酸転移 酵素遺伝子ファミリーに属すると考えられる。マウスC4STは脳 と腎臓で比較的強い発現がみられた(27)。一方ヒトC4STは末梢 白血球、大腸ガン由来の細胞で高い発現が見られた $(30 、 31) 。$ C4STおよびC4STと相同性を示しC4ST活性を持つ第二の遺伝子 C4ST-2 が HNK-1硫酸転移酵素と相同性を示すタンパク質とし て独自にクローニングされた (30)。C4ST-2 の特異性は C4STと 似ていると考えられるが、発現した酵素の活性はC4STに比べて 低かった。ヒトC4ST遺伝子は12q23.2-q23.3にマップされた $(31)$

\section{D-3. ウロノシル2-O-硫酸転移酵素(UA2OST)}

ヘパラン硫酸のIdoA-GlcN($\left(\mathrm{SO}_{3}\right)$ 二糖単位の IdoAの 2 位に硫 酸基を転移し、bFGF 認識ドメインの合成に関与するへパラン硫 酸 2 硫酸転移酵素(32) と相同性を示寸遺伝子の中から UA2OST がクローニングされた(33)。このcDNAを Sf9昆虫細胞にトラン スフェクトすると、デルマタン硫酸とコンドロイチン硫酸に硫 酸基を転移する活性が発現した。デルマタン硫酸の硫酸化は $\operatorname{GalNAc}\left(4 \mathrm{SO}_{4}\right)$ の非還元側に隣接するIdoAの 2 位で起きることが 示された。コンドロイチン硫酸の硫酸化活性はデルマタン硫酸 よりも低いが、GalNAc $\left(6 \mathrm{SO}_{4}\right)$ の非還元側に隣接する GlcAの 2 位 で起きることが示された。

\section{D-4. GalNAc4硫酸6-O-硫酸転移酵素(GaINAc4S-6ST)}

コンドロイチン硫酸Eを大量に含むイカの軟骨から、 GalNAc $\left(4 \mathrm{SO}_{4}\right)$ 残基の 6 位に硫酸基を転移してコンドロイチン硫 酸Eの 2 糖単位を合成する硫酸転移酵素、GalNAc4硫酸 6-O-硫 酸転移酵素(GalNAc4S-6ST)が均一に精製された(34)。精製酵素 はSDS-PAGEで63 kDaの幅広いバンドを示し、N-グリカナーゼ 消化により、38と40kDaに変化したことから GalNAc4S-6STは C6STや C4ST と同じく、N結合糖鎖を含む糖タンパク質と考え られる。精製酵素はコンドロイチン硫酸A、C、デルマタン硫酸 に硫酸基を転移した。コンドロイチンも受容体活性を示した。 コンドロイチン硫酸A、デルマタン硫酸の硫酸化は、繰り返し2 糖部分のGalNAc( $\left.4 \mathrm{SO}_{4}\right)$ 残基の 6 位に起きた。コンドロイチンの 硫酸化も、主要な構成糖であるGalNAcではなく、やはりGalNAc $\left(4 \mathrm{SO}_{4}\right)$ 残基の 6 位に起きた。非還元末端にGalNAc $\left(4 \mathrm{SO}_{4}\right)$ 残基を 持つコンドロイチン硫酸 $\mathrm{A} 由$ 来の 3 糖、5 糖を基質としたとき

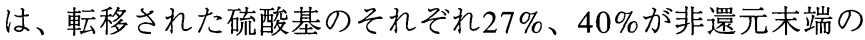
GalNAc $\left(4 \mathrm{SO}_{4}\right)$ に取り込まれることから、この酵素は糖鎖内部の 繰り返し二糖部分だけでなく、非還元末端の GalNAc $\left(4 \mathrm{SO}_{4}\right)$ 残基 にも硫酸基を転移することが示された。コンドロイチン硫酸 $\mathrm{A}$ とデルマタン硫酸を基質にしたときの $K_{\mathrm{m}}$ を比較すると、デルマ 
dermatan sulfate.

\section{E. Sulfotransferases That Belong to C6ST Gene Family}

\section{E-1. Nervous System Involved Sulfotransferase (NSIST)}

A mAb 3B3, which recognized agrin-binding proteins, was raised using the synaptic membrane proteins as the antigen (35). The reactivity of the mAb was decreased by the digestion with neuraminidase but not affected by digestion with chondroitinase or keratanase. This suggests that the epitope for the $\mathrm{mAb}$ may be oligosaccharides with sialic acid. NSIST cDNA was cloned from Torpedo electric organ by expression cloning using mAb 3B3 (36). Amino acid sequence of NSIST showed $56 \%$ identity with that of chick C6ST, suggesting that NSIST may be a sulfotransferase having similar specificity to C6ST. We found that transfection of NSIST cDNA in COS-7 cells resulted in the overexpression of C6ST activity (unpublished data). However, it is not obvious how C6ST activity of NSIST is involved in the synthesis of the $3 \mathrm{~B} 3$ eitope. One of the epitopebearing proteins was found to be dystroglycan. The structure of major O-linked oligosaccharide of dystroglycan was reported to be NeuAc $\alpha 1-3$ Gal $\beta 1-4$ GlcNAc$\beta 1-2 M a n-O-$ (37). NSIST might be involved in the sulfation of such an oligosaccharide chain. It remains to be studied to clear the natural substrate for NSIST.

\section{E-2. Keratan Sulfate Gal-6-Sulfotransferase (KSGal6ST)}

Keratan sulfate bears sulfate at position 6 of Gal residue and position 6 of GlcNAc residue. KSGal6ST was cloned from human fetal brain library by cross hybridization with chick C6ST cDNA (38). KSGal6ST expressed in COS-7 cells catalyzed the transfer of sulfate to position 6 of Gal residue contained in keratan sulfate, sialyl lactosamine oligosaccharides and fetuin oligosaccharides (39). Although the rate of sulfation of sialyl lactosamine oligosaccharide by C6ST was much lower than the rate of sulfation of keratan sulfate by C6ST, the sulfation of sialyl lactosamine oligosaccharide by KSGal6ST proceeded at nearly the same rate as the sulfation of keratan sulfate by KSGal6ST. KSGal6ST may function in the reconstitution of ligand for Lselectin because when KSGal6ST was introduced into $\mathrm{CHO}$ cells, which had been transfected with fucosyl transferase VII and core $2 \beta 1-6 \mathrm{GlcNAc}$ transferase, enhanced binding activity to L-selectin/IgM chimera was detected (40). Northern blot anlysis showed that human KSGal6ST was expressed in the brain (38) and various immunologically relevant tissues (39).

\section{E-3. GlcNAc 6-O-Sulfotransferase Family}

Sulfation of position 6 of GlcNAc residue of glycoprotein oligosaccharides was reported to occur when the GlcNAc residue is located at the nonreducing terminal (41-43). Several kinds of GlcNAc 6-O-sulfotransferase, which transfer sulfate to position 6 of the nonreducing terminal GlcNAc, have been cloned on the basis of homology with C6ST, KSGal6ST or cloned
タン硫酸の方が約 1 桁小さかった。

\section{E. C6STファミリーに属する硫酸転移酵素}

E-1. 神経系硫酸転移酵素(Nervous system involved sulfotransferase, NSIST)

アグリンと結合するタンパク質を認識する単クローン抗体 3B3は、シビレエイのシナプス膜タンパク質を抗原として作製さ れた(35)。3B3 のエピトープはノイラミニダーゼ消化により 3B3 との反応性が減少すること、コンドロイチナーゼやケラタナー ゼ消化では変化しないことから、シアル酸を持つオリゴ糖と考 えられた。3B3 抗体を用いる発現クローニングにより、シビレ エイの発電器官からNSIST 遺伝子がクローニングされた(36)。 NSISTはニワトリC6STとアミノ酸配列が 56\%一致することか ら、C6STと似た特異性の硫酸転移酵素と考えられたが、実際に COS-7細胞に導入するとC6ST活性が発現した(筆者ら未発表)。 しかし、NSISTがC6ST活性を示すことと、3B3と反応するエピ トープとの関係は明らかではない。3B3と反応するエピトープを 持つタンパク質の一つにジストログリカンがある。ジストログ リカンには NeuAc $\alpha$ 1-3Gal $\beta$ 1-4GlcNAc $\beta$ 1-2Man-O-という糖鎖 が含まれることが知られている(37)。このような糖鎖の硫酸化と NSISTが関連を持つことも考えられるが、NSISTの基質の確定に は今後の研究が必要である。

\section{E-2. ケラタン硫酸Gal-6-硫酸転移酵素(KSGal6ST)}

ケラタン硫酸は GlcNAcの 6 位と Galの 6 位が硫酸化されて いる。C6STの相同遺伝子としてKSGa16STがクローニングされ た(38)。COS-7細胞で発現したタンパク質は、ケラタン硫酸、シ アリルラクトサミンオリゴ糖、フェツインに含まれる Gal 残基 の 6 位を硫酸化する活性を示した (39)。C6STによるシアリルラ クトサミンオリゴ糖の硫酸化はコンドロイチンやケラタン硫酸 の硫酸化に比べてずっと遅い速度でしか進まないのに対し、 KSGal6STによるシアリルラクトサミンオリゴ糖の硫酸化はケラ タン硫酸の硫酸化と同じ程度で起きた。フコース転移酵素VII と コア2 $\beta$ 1-6GlcNAc 転移酵素とともに KSGal6ST 遺伝子を導入 した CHO 細胞では、Lセレクチンとの結合活性が上昇したこと から、KSGa16STは Lセレクチンリガンドの合成に機能している と考えられる(40)。ヒト組織での発現をノーザンブロットで調ベ ると、KSGal6ST は脳 (38)や種々の免疫組織(39)で発現してい た。

\section{E-3. GlcNAc 6-O-硫酸転移酵素群}

糖タンパク質の糖鎖の GlcNAc残基の 6 位の硫酸化は、 GlcNAcが非還元末端にある時にのみ起こることが報告されてい る(41-43)。非還元末端の GlcNAc 残基の 6 位を硫酸化する硫酸 転移酵素(GlcNAc 6-O-硫酸転移酵素)が何種類かクローニングさ れた。これらの遺伝子のクローニングでは、C6ST、KSGal6ST あるいはクローニングされたGlcNAc 6-O-硫酸転移酵素と相同性 を示す遺伝子をESTデータベースで検索する方法が基礎となっ ている。記述を簡略化するため、GlcNAc 6-O-硫酸転移酵素群に 
Trends in Glycoscience and Glycotechnology Vol.12 No.67 (September 2000) pp.307-319

GlcNAc 6-O-sulfotransferase. To simplify the description, I have used abbreviations GN6ST-1, GN6ST-2, GN6ST-3 and GN6ST4 for the members of GlcNAc 6-O-sulfotransferase family in the following sections.

Macular corneal dystrophy (MCD) is an autosomal recessive inheritance disorder which accompanies corneal opacity. The corneal explants of MCD has been reported to synthesize low sulfated keratan sulfate, suggesting that sulfotransferase involved in the synthesis of keratan sulfate may be mutated (44 46). When sulfotransferase activities contained in the extracts from the cornea of patients with MCD were determined, we found that GlcNAc6ST activity decreased in MCD patients, although Gal 6-O-sulfotransferase activity of MCD was nearly the same as the control (47). MCD gene was mapped to 16q22 (48). Among GlcNAc 6-O-sulfotransferase so far cloned, GN6ST-2 and GN6ST-3 were mapped to near the MCD locus, and are possibly related with the expression of MCD phenotype. Alternatively, unidentified GlcNAc 6-O-sulfotransferase might be present in the cornea.

\section{E-3-1. GN6ST-1 (GIcNAc 6-O-sulfotransferase)}

The initially cloned GlcNAc 6-O-sulfotransferase, GN6ST-1, transferred sulfate to position 6 of nonreducing terminal GlcNAc residues of GlcNAc $\beta 1-3 \mathrm{Gal} \beta 1-4 \mathrm{GlcNAc}$ or GlcNAc $\beta 1-3 \mathrm{Gal} \beta 1-4 \mathrm{GlcNAc} \beta 1-3 \mathrm{Gal} \beta 1-4 \mathrm{GlcNAc}(49,50)$. When GN6ST-1 cDNA was singly transfected in COS-7 cells, 6-sulfo sialyllactosamine was expressed. When GN6ST-1 and fucosyltransferase VII cDNA were cotransfected in COS-7 cells, 6-sulfo sialyl Lewis $\mathrm{x}$ was expressed. Human endothelial cell line, ECV304, which was cotransfected with GN6ST-1 and fucosyltransferase VII cDNA, expessed 6-sulfo sialyl Lewis X and showed significant adhesion activity to L-selectin-expressing cells (51). mRNA of GN6ST-1 was ubiquitously expressed in various human tissues (50). Benzylglycosides having GlcNAc residue at the nonreducing terminal, GlcNAc $\beta 1-\mathrm{OBz}$ and GlcNAc $\beta 1-6 \mathrm{GlcNAc} \alpha 1-\mathrm{OBz}$ served as acceptors for GN6ST1; GlcNAc $\beta 1-6 \mathrm{GlcNAc} \alpha 1-\mathrm{OBz}$ was a better acceptor. GN6ST1 was shown to transfer sulfate, albeit at a lower rate, to a trisaccharide glycolipid containing internal GlcNAc residue, Gal $\beta 1$ $4 \mathrm{GlcNAc} \alpha 1-6 \mathrm{Gal} \beta 1-\left(\mathrm{CH}_{2}\right)_{2} \mathrm{CONHC}_{8} \mathrm{H}_{17}$, suggesting that GN6ST-1 appears to be able to transfer sulfate to GlcNAc residue located not only at the nonreducing terminal but also at the internal position (52). Human GN6ST-1 gene was mapped to $7 \mathrm{q} 31(50)$ or $3 \mathrm{q} 24$ (53).

E-3-2. GN6ST-2 (HEC-GIcNAc-6-O-Sulfotransferase, LSelectin Ligand Sulfotransferase (LSST))

GN6ST-2 was cloned as a GlcNAc 6-O-sulfotransferase whose expression was highly restricted to $\operatorname{HEV~}(40,54)$.Transfection of cDNA of GN6ST-2, KSGal6ST and CD34 in CHO/ FTVII/C2GnT, which had been stably transfected with fucosyltransferase VII and core $2 \beta 1-6$ GlcNAc transferase cell, resulted in the appearance of L-selectin binding activity. The
属する酵素の略称として、GN6ST-1、GN6ST-2、GN6ST-3、 GN6ST-4を以下の記述で用いた。

斑状角膜変成症(MCD)は角膜の濁りを生じる常染色体劣性 の遺伝疾患である。MCD患者の角膜ではケラタン硫酸の低硫酸 化が起きており(44-46)、ケラタン硫酸合成に関わる硫酸転移酵 素に変異がある可能性が考えられた。MCD 患者の角膜の抽出液 に含まれるケラタン硫酸合成に関連する硫酸転移酔素活性を測 定したところ、Gal 残基の 6 位を硫酸化する活性は対照と変わ らないのに対し、非還元末端の GlcNAc残基の 6 位を硫酸化す る活性が選択的に減少していた(47)。MCD遺伝子は16q22にマッ プされている(48)。今までにクローニングされた GlcNAc 6-O-硫 酸転移酵素のうち、GN6ST-2 と GN6ST-3 は MCD遺伝子の近く にマップされているので、MCDとの関連があるかもしれない。 あるいはまだ知られていない角膜で選択的に発現するGlcNAc 6O-硫酸転移酵素が存在することも考えられる。

\section{E-3-1. GN6ST-1 (GlcNAc 6-O-硫酸転移酔素)}

GlcNAc 6-O-硫酸転移酵素活性を持つ酵素として最初にク ローニングされたGN6ST-1は、GlcNAc $\beta$ 1-3Gal $\beta$ 1-4GlcNAc、 GlcNAc $\beta$ 1-3Gal $\beta$ 1-4GlcNAc $\beta$ 1-3Gal $\beta$ 1-4GlcNAcを基質にした とき末端のGlcNAc残基の 6 位に硫酸基を転移した(49、50)。こ の遺伝子を単独でCOS-7細胞に導入すると6スルホシアリルラク トサミンが、フコース転移酵素VII と同時に導入すると6スルホ シアリルルイス $\mathrm{x}$ が合成された。ヒト内皮細胞の培養細胞 ECV304にフコース転移酵素VII cDNA と同時にGN6ST-1 cDNA を導入すると、6スルホシアリルルイスxが発現し、Lセレクチ ンを発現する細胞との接着活性が著明に増加した(51)。GN6ST1の mRNAはヒトでは調べた限りほとんどの組織で普遍的に発現 していた(50)。非還元末端にGlcNAc残基を持ち、アグリコンと してベンジル基を持つグリコシド、GlcNAc $\alpha 1-\mathrm{OBz} 、 G \mathrm{GlcNAc} \beta 1$ OBz、GlcNAc $\beta$ 1-6GlcNAc $\alpha$ 1-OBzがGN6ST-1の基質となった。 そのうち GlcNAc $\beta$ 1-6GlcNAc $\alpha$ 1-OBzが最も高い活性を示し た。内部にGlcNAc残基を持つ 3 糖誘導体 Gal $\beta$ 1-4GlcNAc $\alpha$ 1$6 \mathrm{Gal} \beta$ 1- $\left(\mathrm{CH}_{2}\right)_{2} \mathrm{CONHC}_{8} \mathrm{H}_{17}$ がGN6ST-1の基質となることから、 GN6ST-1は非還元末端だけでなく内部にあるGlcNAc残基にも硫 酸基を転移すると思われる(52)。GN6ST-1遺伝子はヒト染色体の 7q31 (50)または3q24 (53)にマップされた。

E-3-2. GN6ST-2(HEC-GICNAc 6-O-硫酸転移酵素, L 一セレク チンリガンド硫酸転移酵素 (LSST))

高内皮細静脈に特異的に発現している遺伝子としてGN6ST2がクローニングされた(40、54)。フコース転移酵素VII とコア $2 \beta$ 1-6 GlcNAc転移酵素を導入したCHO細胞に、GN6ST-2、 KSGal6ST、CD34遺伝子を導入すると、Lセレクチンとの結合活 性が出現した。GN6ST-2とKSGa16STはそれぞれ単独で導入した 
combination of GN6ST-2 and KSGal6ST produced strongly enhanced biding of L-selectin, which greatly exceeded the sum of the signals from the individual sulfotransferases (40). GN6ST2 was shown to exhibit striking catalytic preference for core 2branched mucin-type O-glycans as found natural L-selectin counter-receptor (54). Human GN6ST-2 and GN6ST-3 genes were reported to be clustered in band 16q23.1-23.2 (40). GN6ST2 transferred sulfate in vitro to GlcNAc $\beta 1-\mathrm{OBz}$, GlcNA c $\alpha 1-$ $\mathrm{OBz}, \mathrm{GlcNAc} \beta 1-6 \mathrm{GlcNAc} \alpha 1-\mathrm{OBz}, \mathrm{GlcNAc} \beta 1-\mathrm{O}\left(\mathrm{CH}_{2}\right)_{7} \mathrm{CH}_{3}$ and GlcNAc $\beta 1-6 \mathrm{Gal} \alpha 1-\left(\mathrm{CH}_{2}\right)_{2} \mathrm{CONHC}_{8} \mathrm{H}_{17}(40)$.

\section{E-3-3. GN6ST-3 (I-GlcNAc-6-O-sulfotransferase)}

When COS-7 cells were transfected with GN6ST-3 cDNA together with GlyCAM-1 cDNA and metabolically labeled with ${ }^{35} \mathrm{SO}_{4}{ }^{35} \mathrm{SO}_{4}$ was incorporated into position 6 of GlcNAc residue contained in GlyCAM-1 oligosaccharides. Human GN6ST-3 mRNA was mainly expressed in colon and small intestine (55).

E-3-4. GN6ST-4 (Chondroitin 6-Sulfotransferase-2 (C6ST-

\section{2), GIcNAc-6-O-Sulfotransferase 4, GST-5)}

A soluble form of recombinant GN6ST-4 transferred sulfate to position 6 of GalNAc residue of chondroitin. Unlike C6ST, GN6ST-4 did not transfer sulfate to keratan sulfate (25). A microsomal fraction prepared from $\mathrm{CHO}$ cells that had been transfected with GN6ST-4 transferred sulfate to position 6 of GlcNAc residue of GlcNAc $\beta 1-6 \mathrm{Man}-\mathrm{OMe}$. GlcNAc $\beta 1-2 \mathrm{Man}$, GlcNAc $\beta 1-6[G a 1 \beta 1-3]$ GalNAc-pNP and GlcNAc $\beta 1-3 G a 1 \beta 1-$ $4 \mathrm{Glc}$, but not Gal $\beta 1-4 \mathrm{GlcNAc} \beta 1-3 \mathrm{Gal} \beta 1-4 \mathrm{Glc}$, also served as acceptors. Activity toward chondroitin was $2 \%$ of the activity toward GlcNAc $\beta 1-6 \mathrm{Man}-\mathrm{OMe}$ (55). A soluble form of recombinant GN6ST-4 transferred sulfate to GlcNA c $\beta 1-\mathrm{OBz}$, GlcNAc $\beta 1-6 \mathrm{GlcNAc} \alpha 1-\mathrm{OBz}, \mathrm{GlcNAc} \beta 1-\mathrm{O}\left(\mathrm{CH}_{2}\right)_{7} \mathrm{CH}_{3}$ and GlcNAc $\beta 1-6 \mathrm{Gal} \alpha 1-\left(\mathrm{CH}_{2}\right)_{2} \mathrm{CONHC}_{8} \mathrm{H}_{17}$. Human GN6ST-4 was mapped to Xp11.

\section{F. Sulfotransferases That Belong to C4ST Gene Family}

\section{F-1. HNK-1 Sulfotransferase (HNK-1ST)}

HNK-1 epitope has been demostrated to be expressed specifically in the neural tissues and implicated in the movement of neurons and the formation of neural network. The HNK1 epitope contained $\mathrm{GlcA}\left(3 \mathrm{SO}_{4}\right)$ residue at the nonreducing terminal of N-linked oligosaccharides or glycolipids. A sulfotransferase (HNK-1 sulfotransferase) responsible for the formation of $\mathrm{GlcA}\left(3 \mathrm{SO}_{4}\right)$ was cloned by the expression cloning using an antibody for HNK-1 antigen $(57,58)$. When C4ST cDNA was cloned on the basis of the amino acid sequence, a significant homology was observed between C4ST and HNK-1 sulfotransferase (27).

\section{F-2. GalNAc 4-Sulfotransferase (GalNAc4ST)}

Nonreducing terminal GalNAc $\left(4 \mathrm{SO}_{4}\right)$ residue is present in oligosaccharides attached to pituitary glycoprotein hormones, and was shown to play an important role in a pulsatile appear-
ときよりも組み合わせて導入したときの方がLセレクチン結合 活性が高くなった(40)。GN6ST-2はコア2 型のO-グリカンを選択 的に硫酸化することが示された。これは生体内での L-セレクチ ンリガンドがコア2 型のO-グリカンに発現するのに対応してい る (54)。GN6ST-2遺伝子はGN6ST-3遺伝子と16q23.1-23.2にクラ スターをつくっていると報告されている(40)。in vitroでは GlcNAc $\beta 1$-OBz 、GlcNA c $\alpha 1-\mathrm{OBz}$ 、GlcNAc $\beta 1$-6GlcNAc $\alpha 1$ $\mathrm{OBz} 、$ GlcNAc $\beta 1-\mathrm{O}\left(\mathrm{CH}_{2}\right)_{7} \mathrm{CH}_{3}$ 、 GlcNAc $\beta 1-6 \mathrm{Gal} \alpha 1-\left(\mathrm{CH}_{2}\right)_{2}$ $\mathrm{CONHC}_{8} \mathrm{H}_{17}$ が GN6ST-2 の基質となった(40)。

\section{E-3-3. GN6ST-3 (I-GIcNAc 6-O-sulfotransferase)}

GN6ST-3 cDNAをGlyCAM-1 cDNA と同時にCOS-7細胞に導 入し、代謝的に ${ }^{35} \mathrm{SO}_{4}$ でラベルすると、GlyCAM-1糖鎖に含まれ るGlcNAc残基の 6 位に硫酸基が取り込まれた。GN6ST-3の mRNAは大腸、小腸で強く発現していた(55)。

E-3-4. GN6ST-4(コンドロイチン 6 硫酸転移酵素-2 (C6ST-2), GlcNAc 6-O-硫酸転移酵素-4, GST-5)

可溶性のリコンビナントGN6ST-4はコンドロイチンの GalNAc残基の 6 位を硫酸化した。C6STと異なり、ケラタン硫 酸を硫酸化しなかった(25)。GN6ST-4 cDNAを導入したCHO細胞 から調製したミクロゾーム画分は、GlcNAc $\beta$ 1-6Man-OMeの GlcNAc残基のの 6 位に硫酸基を転移した。GlcNAc $\beta$ 1-2Man、 GlcNAc $\beta$ 1-6[Gal $\beta$ 1-3]GalNAc-pNP、GlcNAc $\beta$ 1-3Gal $\beta$ 1-4Glc ซ アクセプター活性を示したが、Gal $\beta$ 1-4GlcNAc $\beta$ 1-3Gal $\beta$ 1-4Glc は基質にならなかった。コンドロイチンを硫酸化する活性は、

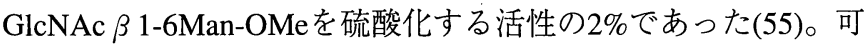
溶性のリコンビナントGN6ST-4は、GlcNA c $\beta$ 1-OBz、GlcNAc $\beta 1$ 16GlcNAc $\alpha 1-\mathrm{OBz} 、 \mathrm{GlcNAc} \beta 1-\mathrm{O}\left(\mathrm{CH}_{2}\right)_{7} \mathrm{CH}_{3} 、 \mathrm{GlcNAc} \beta 1-6 \mathrm{Gal} \alpha 1-$ $\left(\mathrm{CH}_{2}\right)_{2} \mathrm{CONHC}_{8} \mathrm{H}_{17}$ を硫酸化する活性を示した (52)。GN6ST-4遺伝 子はヒト染色体の Xp11にマップされている。

\section{F. C4STファミリーに属する硫酸転移酵素}

\section{F-1. HNK-1 硫酸転移酵素 (HNK-1ST)}

HNK-1エピトープは神経組織で選択的に発現しており、神 経細胞の移動、ネットワークの形成などに機能していると考え られている。HNK-1エピトープにはN 結合糖鎖の非還元末端に 結合しているGlcA-3-O-硫酸という構造が含まれるが、この硫酸 基の転移反応を行う HNK-1硫酸転移酵素が発現クローニングに よりクローニングされた (57、58)。 :アミノ酸配列に基づきC4ST がクローニングされた結果、C4STとHNK-1硫酸転移酵素は有意 な相同性を示すことが明らかになった(27)。

\section{F-2. GalNAc 4-硫酸転移酵素}

脳下垂体の糖タンパク質ホルモンlutropinの糖鎖の非還元末 端GalNAc4-硫酸残基は、肝臟にある特異的なレセプターと結合 することにより、lutropinの血液中の滞在時間を調節する機能が 


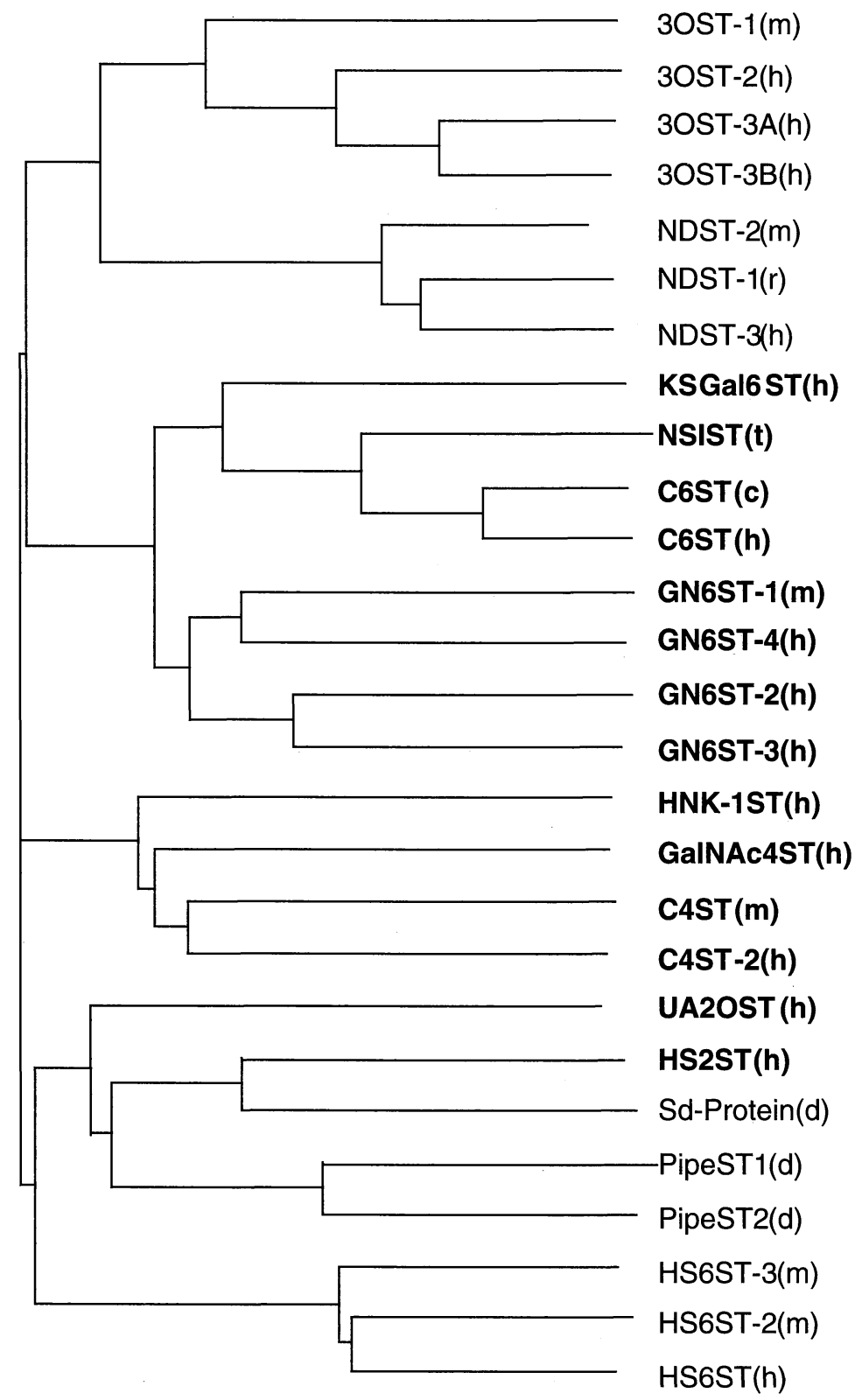

Fig. 2. Sequence-based evolutionary tree of the various glycosaminoglycan sulfotransferases. In the dendrogram obtained with the program Clustal W, branch length (horizontal lines) is approximately proportional to evolutionary distances. For the abbreviation of each sulfotransferase, see the text. Sulfotransferases described in this revlew are shown in bold letters. Letters in parentheses represent the species: $m$, mouse; $h$, human; $r$, rat; $t$, Torpedo; $c$, chick; $d$, Drosophila.

ance of lutropin in the blood through the binding to the hepatic receptor for the sulfated GalNAc residue $(59,60)$. GalNAc4ST, which transfers sulfate to position 4 of nonreducing terminal GalNAc residue, was cloned by two groups independently $(61$, 62). Identity of the amino acid sequence between GalNAc4ST and human C4ST was $30 \%$. The recombinant GalNAc4ST did not transfer sulfate to chondroitin or desulfated dermatan sulfate that served as acceptors for C4ST, but transferred to car-
あると考えられている(59、60)。非還元末端GalNAc4-硫酸転移 酵素の遺伝子がC4STと相同性を示す遺伝子として同時に 2 力所 の研究室でクローニングされた(61、62)。GalNAc4ST はC4STと アミノ酸配列が $30 \%$ 一致した。発現した酵素は C4STの基質で あるコンドロイチン、脱硫酸化デルマタン硫酸を硫酸化せず、 カルボニックアンヒドラーゼVI、GalNAc 残基を非還元末端に 持つ合成糖鎖を硫酸化した。非還元末端 GalNAc 残基の 4 位が 選択的に硫酸化された。GalNAc4ST遺伝子は脳下垂体で最も強 
bonic anhydrase VI and synthetic glycosides having GalNAc residue at the nonreducing terminal. Sulfation ocurred at position 4 of the nonreducing terminal GalNAc residue. The message of GalNAc4ST was expressed strongly in the human pituitary, suggesting that GalNAc4ST may be involved in the synthesis of the nonreducing terminal GalNAc $\left(4 \mathrm{SO}_{4}\right)$ residues found in the $\mathrm{N}$-linked oligosaccharides of pituitary glycoprotein hormones. By searching the human genome data base, GalNAc4ST gene was found to be mapped to $19 \mathrm{q} 13.1$, and to be composed of at least four exons. As observed in C4ST, GalNAc4ST also contains Cys in 5'-PSB domain, which has not been found in glycosaminoglycan sulfotransferases so far cloned. Although the functional role of this Cys residue is not clear at present, Cys in 5'-PSB domain may be relevant to the stimulation of GalNAc4ST and C4ST by sulfhydryl compounds.

\section{G. Future Prospects for the Study of Sulfotransferases}

Marked progress in the cloning of the sulfotransferases involved in the synthesis of glycosaminoglycans has been achieved recently. Among the sulfotransferases involved in the synthesis of chondroitin sulfate, GalNAc4S-6ST has not been cloned yet. If cloning of GalNAc4S-6ST is attained, nearly all the genes of sulfotransferases involved in the synthesis of chondroitin sulfate isomers (chondroitin sulfate A, C, D and E) will become available. As shown in Fig. 2, divergent glycosminoglycan sulfotransferases are thought to have evolved from a small number of common ancestral genes. During their evolution, sulfotransferases with a unique substrate specificity may appear and they may support the higher biological phenomena such as immunological cellular interaction and neural function. From the gene families showing homology with sulfotransferases so far cloned, a unique sulfotransferase with important biological functions may be found. Studies on the substrate specificity and regulation of gene expression of sulfotransferases will offer important information to elucidate the biological function of sulfated sugar in the celluar interactions in multicelluar organisms.
く発現しており、脳下垂体ホルモンの $\mathrm{N}$ 結合糖鎖の非還元末端 にある GalNAc $\left(4 \mathrm{SO}_{4}\right)$ 残基の合成に関わっていることが強く示唆 された。この遺伝子を持つヒトゲノムクローンの検索から、 GalNAc4STは19q13.1にマップされ、少なくとも4 個のエキソン を含むことが分かった。C4STと同様にGalNAc4STはPAPS結合 ドメインと推定される5'-PSBドメインにCysを含んでいる。今 までにクローニングされたグリコサミノグリカン硫酸転移酵素 の中には5'-PSBドメインにCysを含んでいる硫酸転移酵素は他に は知られていない。この Cysの機能は明らかではないが、C4ST と GalNAc4STがどちらも SH化合物により活性化されることと 関連があるかもしれない。

\section{G. 硫酸転移酵素研究の今後の展望}

コンドロイチン硫酸異性体合成に関わる硫酸転移酵素の遺 伝子クローニングは、この数年の間に大きな進展があった。コ ンドロイチン硫酸の合成に関与する硫酸転移酵素のうち、 GalNAc4S-6STはまだクローニングされていない。GalNAc4S6STがクローニングされれば、コンドロイチン硫酸A、C、D、E という異性体合成に関わるほぼすべての硫酸転移醅素の遺伝子 操作が可能となるであろう。図2に示すように、糖鎖硫酸化反応 を行う多様な硫酸転移酵素は、少数の共通の祖先から進化して きたと考えられる。この進化の過程で、特異な基質特異性を もった硫酸転移酵素が出現し、それらが免疫現象や神経機能な どの高度な生物学的現象を支えてきたかもしれない。今までに クローニングされた硫酸転移酵素と相同性を示す遺伝子ファミ リーの中から、重要な生物学的機能を持った硫酸転移酵素が見 いだされるかもしれない。硫酸転移酵素の特異性と遺伝子発現 の調節の研究は、多細胞生物の細胞間相互作用における糖鎖硫 酸化の生物学的役割を明らかにするための重要な情報を提供す るであろう。

\section{References}

1. Habuchi, H., Habuchi, O., and Kimata, K. (1998) Trends in Glycoscience and Glycotechnology 10, 65-80

2. Habuchi, O. (2000) Biochim. Biophys. Acta 1474, 115-127

3. Hastbacka, J., de la Chapelle, A., Mahtani, M.M., Clines, G., Reeve-Daly, M.P., Daly, M., Hamilton, B.A., Kusumi, K., Trivedi, B., Weaver, A., Coloma, A., Lovett, M., Buckler, A., Kaitila, I, and Lander, E.S. (1994) Cell 78, 1073-1087

4. Superti-Furga, A., Hastbacka, J., Wilcox, W. R., Cohn, D.H., van der Harten, J.J., Rossi, A., Blau, N., Rimoin, D.L., Steinmann, B., Lander, E.S., and Gitzelmann, R. (1996) Nat. Genet. 12, 100-102

5. Rossi, A., Bonaventure, J., Delezoide, A-L., Superti-Furga, A., and Cetta, G. (1997) Eur. J. Biochem. 248, 741-747

6. Rossi, A., Bonaventure, J., Delezoide, A-L., Cetta, G., and Superti-Furga, A. (1996) J. Biol. Chem. 271, 18456-18464

7. Girard, J-P., Baekkevold, E.S., Feliu, J., Brandtzaeg, P., and Amalric, F. (1999) Proc. Natl. Acad. Sci. USA 96, 12772-12777

8. Pennypacker, J.P., Kimata, L., and Brown, K. (1981) Dev. Biol. 81, 280-287

9. Sugahara, K., and Schwartz, N.B. (1982) Arch. Biochem. Biophys. 214, 589-601

10. Sugahara, K., and Schwartz, N.B. (1982) Arch. Biochem. Biophys. 214, 602-609

11. Lyle, S., Stanczak, J., Ng, K., and Schwartz, N.B. (1994) Biochemistry 33, 5920-5925

12. Li, H., Deyrup, A., Mensch, Jr., J.R., Domowicz, M., Konstantinidis, A. K., and Schwartz, N.B. (1995) J. Biol. Chem. 270, 29453-29459

13. Girard, J-P., Baekkevold, E.S., and Amalric, F. (1998) FASEB J. 12, 603-612

14. Kurima, K., Warman, M.L., Krishnan, S., Domowicz, M., Krueger, Jr., R.C. Deyrup, A., and Schwartz, N.B. (1998) Proc. Natl. Acad. Sci. 
Trends in Glycoscience and Glycotechnology Vol.12 No.67 (September 2000) pp.307-319

USA 95, 8681-8685

15. ul Haque, M.F., King, L.M., Krakow, D., Cantor, R.M., Rusiniak, M.E., Swank, R.T., superti-Furga, A., Haque, S., Abbas, H., Ahmad, M., Cohn, D.H. (1998) Nat. Genet. 20, 157-162

16. Besset, S., Vincourt, J-B. Amalric, F., and Girard, J-P. (2000) FASEB J. 14, 345-354

17. Abeijon, C., Mandon, E.C., and Hirschberg, C.B. (1997) TIBS 22, 203-207

18. Mandon, E.C., Milla, M.E., Kempner, E., and Hirschberg, C.B. (1994) Proc. Natl. Acad. Sci. USA 91, 10707-10711

19. Ozeran, J. D., Westley, J., and Schwartz, N. B. (1996) Biochemistry 35, 3695-3703

20. Habuchi, O., Matsui, Y., Kotoya, Y., Aoyama, Y., Yasuda, Y., and Noda, M. (1993) J. Biol. Chem. 268, 21968-21974

21. Sugumaran, G., Katsman, M., and Drake, R.R. (1995) J. Biol. Chem. 270, 22483-22487

22. Fukuta, M., Uchimura, K., Nakashima, K., Kato, M., Kimata, K., Shinomura, T., and Habuchi, O. (1995) J. Biol. Chem. 270, 18575-18580

23. Habuchi, O., Hirahara, Y., Uchimura, K., and Fukuta, M. (1996) Glycobiology 6, 51-57

24. Habuchi, O., Suzuki. Y., and Fukuta, M. (1997) Glycobiology 7, 405-412

25. Kitagawa, H., Fujita, M., Ito, N., and Sugahara, K. (2000) J. Biol. Chem. 275, 21075-21080

26. Yamauchi, S., Hirahara, Y., Usui, H., Takeda, Y., Hoshino, M., Fukuta, M., Kimura, J.H., and Habuchi, O. (1999) J. Biol. Chem. 274, 24562463

27. Yamauchi, S., Mita, S., Matsubara, T., Fukuta, M., Habuchi, H., Kimata, K., and Habuchi, O. (2000) J. Biol. Chem. 275, 8975-8981

28. Bakker, H., Friedmann, I., Oka, S., Kawasaki, T., Nifant'ev, N., Schaner, M., and Mantei, N. (1997) J. Biol. Chem. 272, 29942-29946

29. Ong, E., Yeh, J-C., Ding, Y., Hindsgaul, O., and Fukuda, M. (1998) J. Biol. Chem. 273, 5190-5195

30. Hiraoka, N., Nakagawa, H., Ong, E., Akama, T, Fukuda, M.N., and Fukuda, M. (2000) J. Biol. Chem, 275, 20189-20196

31. Okuda, T., Mita, S., Yamauchi, S., Matsubara, T., Yagi, F., Yamamori, D., Fukuta, M., Kuroiwa, A., Matsuda, Y., and Habuchi, O. (2000) J. Biochem (in press)

32. Kobayashi, M., Habuchi, H., Yoneda, M., Habuchi, O., and Kimata, K. (1997) J. Biol. Chem. 272, 13980-13985

33. Kobayashi, M., Sugumaran, G., Liu, J., Shworak, N.W., Silbert, J.E., and rosenberg, R.D. (1999) J. Biol. Chem. 274, 10474-10480

34. Ito, Y., and Habuchi, O. (2000) J. Biol. Chem. 275, in press

35. Bowe, M.A., Deyst, K.A., Leszyk, J.D., and Fallon, J.R. (1994) Neuron 12, 1173-1180

36. Nastuk, M.A., Davis, S., Yancopoulos, G.D., Fallon, J.R. (1998) J. Neurosci. 18 7167-7177

37. Chiba, A., Matsumura, K., Yamada, H., Inazu, T., Shimizu, T., Kusunoki, S., Kanazawa, I., kobata, A., and Endo, T. (1997) J. Biol. Chem. 272, $2156-2162$

38. Fukuta, M., Inazawa, J., Torii, T., Tsuzuki, K., Shimada, E. and Habuchi, O. (1997) J. Biol. Chem. 272, 32321-32328

39. Torii, T., Fukuta, M., and Habuchi, O. (2000) Glycobiology 10, 203-211

40. Bistrup, A., Bhakta, S., Lee, J.K., Belov, Y.Y., Gunn, M.D., Zuo, F-R., Huang, C-C., Kannagi, R., Rosen, S.D., Hemmerich, S. (1999) J. Cell Biol. 145, 899-910

41. Spiro, R.G., Yasumoto, Y., and Bhoyroo, V. (1996) Biochem. J. 319, 209-216

42. Degroote, S., Lo-Guidice, J.-M., Strecker, G., Ducourouble, M.-P., Roussel, P., and Lamblin, G. (1997) J. Biol. Chem. 272, 29493-29501

43. Bowman, K.G., Hemmerich, S., Bhakta, S., Singer, M.S., bistrup, A., rosen, S.D., and Bertozzi, C. R. (1998) Chem. Biol. 5, 447-460

44. Hassell, J.R., Newsome, D.A., Krachmer, J.H., Rodrigues, M.M. (1980) Proc. Natl. Acad. Sci. USA 77, 3705-3709

45. Klintworth, G.K., Smith, C.F. (1983) Lab. Invest. 48, 603-612

46. Nakazawa, K., Hassell. J.R., Hascall, V.C., Lohmander, L.S., Newsome, D.A., Krachmer, J. (1984) J. Biol. Chem. 259, 13751-13757

47. Hasegawa, N., Torii, T., Kato, T., Miyajima, H., Furuhata, A., Nakayasu, K., Kanai, A., and Habuchi, O. (2000) Invest. Ophthalmol. Vis. Sci. (in press)

48. Vance, J. M., Jonasson, F., Lennon, F., Sarrica, J., Damji, K.F., Stauffer, J., Pericak-Vance, M.A., and Klintworth, G.K. (1996) Am. J. Hum. Genet. 58, 757-762

49. Uchimura, K., Muramatsu, H., Kadomatsu, K., Fan, Q-W., Kurosawa, N., Mitsuoka, C., Kannagi, R., Habuchi, O., and Muramatsu, T. (1998) J. Biol. Chem. 273, 22577-22583

50. Uchimura, K., Muramatsu, H., Kaname, T., Ogawa, H., Yamakawa, T., Fan, Q.W., Mitsuoka, C., Kannagi, R., Habuchi, O., Yokoyama, I., Yamamura, K., Ozaki, T., Nakagawara, A., Kadomatsu, K., and Muramatsu, T. (1998) J. Biochem. 124, 670-678

51. Kimura, N., Mitsuoka, C., Kanamori, A., Hiraiwa, N., Uchimura, K., Muramatsu, T., Tamatani, T., Kansas, G.S., Kannagi, R. (1999) Proc. Natl. Acad. Sci. USA 96, 4530-4535

52. Bhakta, S., Bartes, A., Bowmann, K.G., Kao, W-M., Polsky, I., Lee, J.K., Cook, B., Bruehl, R., Rosen, S., Bertozzi, C., and Hemmerich, S. (2000) J. Biol. Chem. in press

53. Li, X., and Tedder, T.F. (1999) Genomics 55, 345-347

54. Hiraoka, N., Petryniak, B., Nakayama, J., Tsuboi, S., Suzuki, M., Yeh, J.C., Izawa, D., Tanaka, T., Miyasaka, M., Lowe, J.B., Fukuda, M. (1999) Immunity 11, 79-89

55. Lee, J.K., Bhakta, S., Rosen, S.D., and Hemmerich, S. (1999) Biochem. Biophys. Res. Commu. 263, 543-549

56. Uchimura, K., Fasakhany, F., Kadomatsu, K., Matsukawa, T., Yamakawa, T., Kurosawa, N., and Muramatsu, T. (2000) Biochem. Biophys. Res. Commu. 274, 291-296

57. Bakker, H., Friedmann, I., Oka, S., Kawasaki, T., Nifant'ev, N., Schaner, M., and Mantei, N. (1997) J. Biol. Chem. 272, 29942-29946

58. Ong, E., Yeh, J-C., Ding, Y., Hindsgaul, O., and Fukuda, M. (1998) J. Biol. Chem. 273, 5190-5195

59. Fiete, D., Srivastava, V., Hindsgaul, O., and Baenziger, J.U. (1991) Cell, 67, 1103-1110

60. Baenziger, J.U., Kumar, S., Brodbeck, R. M., Smith, P.L., and Beranek, M.C. (1992) Proc. Natl. Acad. Sci. USA, 89, 334-338

61. Xia, G., Evers, M.R., Kang, H-G., Schachner, M. and Baenziger, J.U. (2000) J. Biol. Chem (in press)

62. Okuda, T., Mita, S., Yamauchi, S., Fukuta, M., Nakano, H., Sawada, T., and Habuchi, O. (2000) J. Biol. Chem (in press)

Received on October 2, 2000, accepted on October 10, 2000 


\section{Profile of the Author}

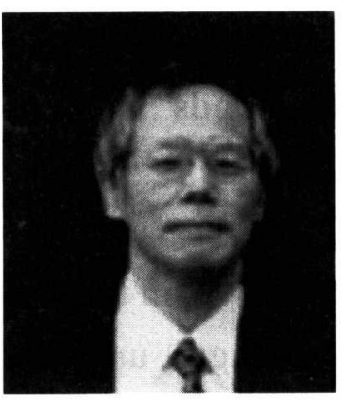

\section{Osami Habuchi}

He undertook undergraduate and graduate studies in Chemistry at Nagoya University. As his first study, he was engaged in the purification of chondroitinase AC from F. heparinum. He received his Ph.D. from Nagoya University in 1972. The title of his thesis is "Biosynthesis of chondroitin sulfate $\mathrm{E}$ in squid cartilage." Since 1972 his professional activity has developed at Aichi University of Education. From1983 to1984, he studied sulfation of chondroitin sulfate using cultured chick embryo chondrocytes at Dr. H. E. Conrad's laboratory in the University of Illinois. His group purified and cloned chondroitin 6-sulfotransferase and chondroitin 4-sulfotransferase. Recently, his group purified GalNAc 4-sulfate 6-O-sulfotransferase that is involved in the synthesis of chondroitin sulfate $\mathrm{E}$. He is now interested in the specificity, molecular nature and biological significance of the sulfotransferases involved in the synthesis of chondroitin sulfate and related sugar chians. 